\title{
UNJUST ENRICHMENT AND THE DEGLMAN CASE
}

\author{
By L. A. Shelton, B.A.
}

In the recent case of Deglman v. Guaranty Trust Co. and Constantineau, the Supreme Court of Canada rather strongly indicated its position in the longstanding controversy as to whether the basis of quasi-contractual actions should be contracts implied by law according to decided cases, or whether the basis should be a broad principle of restitution where there is unjust enrichment. On this question there appear to be three main schools of thought and it is necessary to take a brief look at each of them in order to understand the significance of the Deglman case.

The first school maintains that the existing case law sets out certain situations where a contract will be implied, and that these show the complete extent of quasi-contractual remedies. Any underlying principle of unjust enrish. ment is entirely disclaimed. After 146 years of controversy which began with Lord Mansfield, the proponents of this opinion achieved triumph in England in the 1914 case of Sinclair v. Brougham, ${ }^{2}$ in which Lord Sumner stated:

The action for money had and received cannot now be extended beyond the principles illustrated in the decided cases, and although it is hard to reduce to one common formula the conditions under which the law will imply a.promise to repay money recejved to the plaintiff's use. ... .

and further:

There is now no ground left for suggesting as a recognizable "equity" the right to recover money in personam merely because it would be fair and right thing that it should be refunded to the payer."

This statement by Lord Sumner was a reiteration in the House of Lords of the position he had taken earlier as Hamilton'L.J. when he was sitting in the Court of Appeal in Baylis v. Bishop of London, where he said:

To ask what course would be ex aequo et bono has never been a very precise guide and as a working rule it has long since been buried in Standish v. Ross and Kelly v. Solari.7 Whatever may have been the ease 146 years ago, we are not now free in the twentieth century to administer that vague jurisprudence which is sometimes nttractively styled "justice as between man and man"."

In 1923 Scrutton L.J. showed great alacrity in coming to the support of the victors, quoting Lord Sumner and saying:

... the whole history of this particular form of action bas been what I may call a history of well-meaning sloppiness of thought. ${ }^{9}$

Since that time the doctrine of unjust enrichment has been so out of favour judicially in England that only the most adventuresome of judges have supported it. In Nelson v. Larholt, ${ }^{10}$ Denning. J. stated the principle without being overruled on appeal, because there was no appeal. However, he was not so fortunate when he did the same thing in Reading v. A.G.," for when that case was appealed to the House of Lords, Lord Porter stated:

My Lorda, the exact status of the law of unjust enrichment is not assured. It holds a predominant place in the law of Scotland and I think, of the United States, but I am content for the purposes of this case to accept the view that it forms no part of the law of England and that a right to restitution so deseribed would be too widely stated. ${ }^{12}$ 
Those who hold to the unjust enrichment theory, the members of the second school, in contradiction to Scrutton L.J., maintain that the inadequate thought is to be found in the advocates of the implied contract theory. Their argument is as follows: Quasi-contract should be recognized as a totally distinct form of recovery than either contract or tort. It does not have the express intention or agreement of contract, which may be found in words or implied from facts, nor does it have the nature of tort which is characterized generally by a duty at large and unliquidated damages and which requires a forbearance from acting harmfully. It is maintained that the basis of the action is that the court will order restitution if the justice of the case so requires.

The reason English law is unique in not having a special and distinct head of recovery here is to be found in history. Because actions had to be brought under one of the existing forms, the relief of restitution based upon unjust enrichment, insofar as it was desired in courts of law racher than equity, had to be sought either under contract or tort. It came to be given under contracts implied by law and thus the confusion arose. Courts failed to distinguish between contracts implied in law where there was no possible agreement between the parties, and genuine contracts where the intention of the parties was implied from the facts of the acts of the parties. Rules of contract were applied to quasi-contracts in situations where such rules are inapplicable. For example, Viscount Haldane L.C. said in Sinclair v. Brougham that:

.. actions arising quasi ex contractu ... refers merely to $n$ elass of actions in theory based on a contract which is imputed to the defendant by a fiction of law. The fiction can only be set up with effect if such a contrace would be valid if it really existed. ${ }^{29}$

In this he was as wrong as if he had said that because there can be no action in contract there is none in tort.

However, the supporters of this school do not generally claim that a great deal of injustice is done by refusing to recognize the principle of unjust enrichment. It is conceded that remedies have been found in needy cases by extending the existing principles of tracing in equity, constructive trust, and contracts implied by law. The main point made by the proponents of unjust enrichment is that it is the true basis of recovery in a wide class of cases and should be so recognized in order that a great many fictions, inconsistencies and confusions may be eradicated from the laws.

A few of the leading English exponents of this theory may be mentioned. Lord Mansfield began the controversy about unjust enrichment in the English law by using the principle in such cases as Moses v. McFerlan. ${ }^{14}$ From his time until 1914, when it received a near-fatal blow in Sinclair v. Brougham, ${ }^{20}$ the principle appeared from time to time in the reported cases. Since 1914 its main advocates in English law have been juristic writers such as Professor Winfield ${ }^{16}$ and Dr. Friedmann. ${ }^{17}$

Much weight was added to this side of the argument by the support of Lord Wright in an article ${ }^{18}$ on Sinclair v. Brougham and by dicta in cases such as Fibrosa Spolka Acyjna v. Fairbairn Lawson Combe Barbour, Limited, ${ }^{10}$ where he denies that Sinclair v. Brougham has closed the door to any theory of unjust enrichment. He says: 
It is clenc that any civilized system of law is bound to provide remedies for cases of what has been called unjust enrichment or unjust benefit, that is to prevent a man from retaining the money of or some benefit derived from another which it is against conscience that he should keep. Such remedies in English law are generically different from temedies in contract or in tort, and are now recognized to fall within a third category of the common law which has been called quasi-contract or restitution. ${ }^{20}$

and

Lord Mansfield does not say that the law implies a promise. The law implies a debt or obligation which is a different thing. In fact, he denies that there is a contract; the obligation is as efficacious as if it were upon a contract. The obligation is a creation of the law just as much as an obligation in tort. The obligation belongs to a third class, diatinct from either contract or wot, though it resembles contract rather than tort. ${ }^{21}$

Whether this theory will ever attain wide acceptance in England need not be considered here. At the present time at least it seems that the theory of contracts implied by law is dominant. In the United States, however, the position is quite different. Quasi-contracts and constructive trusts are generally grouped under the broad heading of restitution and in the American Law Institute's Restatement of the Law of Restitution, the underlying principle is stated as follows:

A person who has been unjustly enriched at the expense of another is required to make restitution to the other. ${ }^{22}$

A third school of thought which supports implied contracts for English law while purporting to recognize and answer the unjust enrichment theory is represented by W. S. Holdsworth. He admits that the true basis of implied contract is unjust benefit but maintains that the principle is too broad to be of value, and would render the law uncertain if brought in as a basis of recovery. He says in an article in the Law Quarterly Review:

I conclude that the conditions in which English law gives a remedy for unjustifiable entich. ment are not unreasonable. It may be that they require amendment in some particulars. If so let them be amended. But it would be a remdey far worse than the disense if the basis of the common law rule was scrapped, and for it was substituted a rule which left the whole matter to the discrection of the judge, and if in consequence the equitable modifications of, and supple. ments to, both the proprietory and personal remedies given by the common law were laft in the air. Bettet a system which is too rigid than no system at all. ${ }^{23}$

Brief and incomplete as this summary may be, it will at least point out that there are two possible grounds upon which to allow recovery in quasi-contract cases. The question now is whether the courts in Canada will, in spite of the English cases and the objections of Holdsworth, scrap the basis of the common law rule or whether they will continue to speak of contracts implied by law. It is submitted that the Deglman case shows that the Supreme Court of Canada is prepared to do away with contracts implied by law and give restitution where there is unjust benefit.

The Deglman case was quite simply one where there was an existing unenforceable contract for services, while in justice the plaintiff was entitled to restitution for those services which he had rendered. It arose in the following manner. During her lifetime one Norah Brunet made an oral contract with Constantineau, her nephew, whereby he was to perform certain personal services for her as she should from time to time request. In return she promised to make provision for him in her will and in particular to devise to him a certain house. During Norah Brunet's lifetime, Constantineau performed the services which consisted of doing odd jobs around that house and another one owned 
by Norah Brunet, doing errands for her and taking her on trips and pleasure drives. Upon her death he found that the will did not provide for him and he thereupon sued the Guaranty Trust Co., executors of the will of Norah Brunet, and Beatrice C. Deglman, a beneficiary under the will who represented the next of kin other than Constantineau.

The defendants relied upon section four of the Statute of Frauds, ${ }^{24}$ claiming that the contract, being in relation to lands, was unenforceable by reason of its not being in writing. In the Trial Court and in the Ontario Court of Appeal, ${ }^{25}$ the plaintiff succeeded because it was held that the acts in this case were referable to the existence of a contract and are consistent with the particular contract alleged. They were therefore acts of part performance which take the case out of the statute. On appeal by the defendant Deglman, the Supreme Court of Canada reversed the Ontario Court of Appeal on this point, holding that there were not sufficient grounds to find a part performance. The acts must be unequivocally referable to some dealing with the land in question.

However, we are not now concerned with the question of part performance. Having decided that the contract in question was unenforceable, the Supreme Court went on to hold for the plaintiff Constantineau on other grounds which, it is submitted, squarely accord with the restitution for unjust enrichment theory of quasi-contract. Their support of the unjust benefit school is evidenced by their express words, by their method of dealing with and the nature of the case before them, and by their selection of authorities.

Two judgments were delivered in the Deglman case. In the first Rand J., with the concurrence of Rinfret C.J.C. and Taschereau J., states:

The statute in such a case does not touch the principle of restirution againse what would otherwise be an unjust enrichment of the defendant at the expense of the plaintiff. ${ }^{20}$

In the second judgment, Cartwright J., with the concurrence of Estey, Locke, and Fauteaux JJ., states: law.28

This right appears to me to be based, not on contract, but on an obligation imposed by

Clearly the Supreme Court is here recognizing a type of liability distinct from tort or contract, taking the viewpoint advocated by the second school as discussed previously.

From the nature of the case, rejection of the theory of implied contract can be seen particularly in the judgment of Cartwright $\mathrm{J}$. In looking at two conflicting English cases involving contracts implied by law, the learned judge chose to approve the one which would prevent a remedy in the case before him. In Scott v. Pattison ${ }^{28}$ the plaintiff did recover on an implied contract where an express one was unenforceable by reason of the Statute of Frauds. Cartwright J. comments:

While I respectfully agree with the result arrived at in Scott v. Pattison, I do not think it is accurate to say that there was an implied ptomise. In $m y$ view it was correctly decided in Brifain v. Rossiter (1879), I1 Q.B.D. 123, that where there is an express contract between the parties which turns out to be unenforceable by reason of the Stacute of Frauds, no other contract between the parties can be implied from the doing of acts in performance of an express but unenforceable contract. 20

On this question the learned judge takes the same position as one of Canada's 
unjust enrichment theory advocates, Dr. Cecil A. Wright, who states:

In commenting on Scott v. Pattison an English writer insisted that the result was erroneous, since he staced it to be elementary that when work was done upon an express contract which was unrescinded it was impossible to imply anothet contract. It is possible to agree with this statement without disagreeing with the decision. ${ }^{30}$

In taking this view of the two cases, Cartwright $\mathrm{J}$. was forced to reject the implied contract theory completely in order to grant the relief that he did grant in the Deglman case. He could easily have accepted the implied contract theory and then applied Scott v. Pattison to achieve the result he later arrived at. Instead he chose to reject the fiction entirely.

In dealing with the question of the Limitations Act, Cartwright J. again points out that the nature of the action is distinct from any kind of contract. Argument had been adduced to the effect that the right to recover on an unenforceable contract is limited to the value of services rendered in the six years preceding the commencement of the action. Cases were cited for this proposition, to which Cartwright J. answered:

These cases seem to have proceeded on the view that the liability of the defendant was under "an implied promise to pay a reasonable sum per annum" (see Cross v. Cleary, 29 O.R. at p 545.) I have already indicated my reasons for holding, in the case at bar, no such promise can be implied. In my opinion the obligation which the law imposes upon the respondent administrator did not arise until the deceased died intestate. ${ }^{81}$

In other words, no cause of action arose until the estate was unjustly benefited.

Finally, it is submitted that the Supreme Court's selection of authorities for their judgment is significant to show where it stands. Lord Sumner is ignored completely. The only authority of the House of Lords which is referted to is Lord Wright, who, as has been seen, is a leading warrior in the assault upon contracts implied by law. Cartwright J. not only quotes Lord Wright's statement in the Fibrosa case ${ }^{32}$ on the theory of unjust enrichment, but also quotes Lord Wright's approval of Lord Mansfield's much-attacked theories. Cartwright $J$. then says:

Lord Wright's judgment appears to me to be in agreement with the view stated in Williston on Contracts referred to by my brother Rand. ${ }^{33}$

Turning then to the authorities cited by Rand J., we see that he relies exclu. sively upon the American authorities of the Restatement of the Law of Contract and upon Professor Williston for the proposition that where services are given for land under an oral contract, it is the same as if money had been given.

$\ldots$, it would be inequitable to allow the promisor to keep both the land and the money and the other party is entitled to recover what he has paid.

As has been pointed out earlier, implied contract theory has been generally rejected in the U.S.A.

With due respect to those of opposing opinions, this writer feels that the Deglman case is a step in the right direction. The Supreme Court of Canada buries the forms of action a little deeper, where they will have more difficulty in ruling us in the future. 


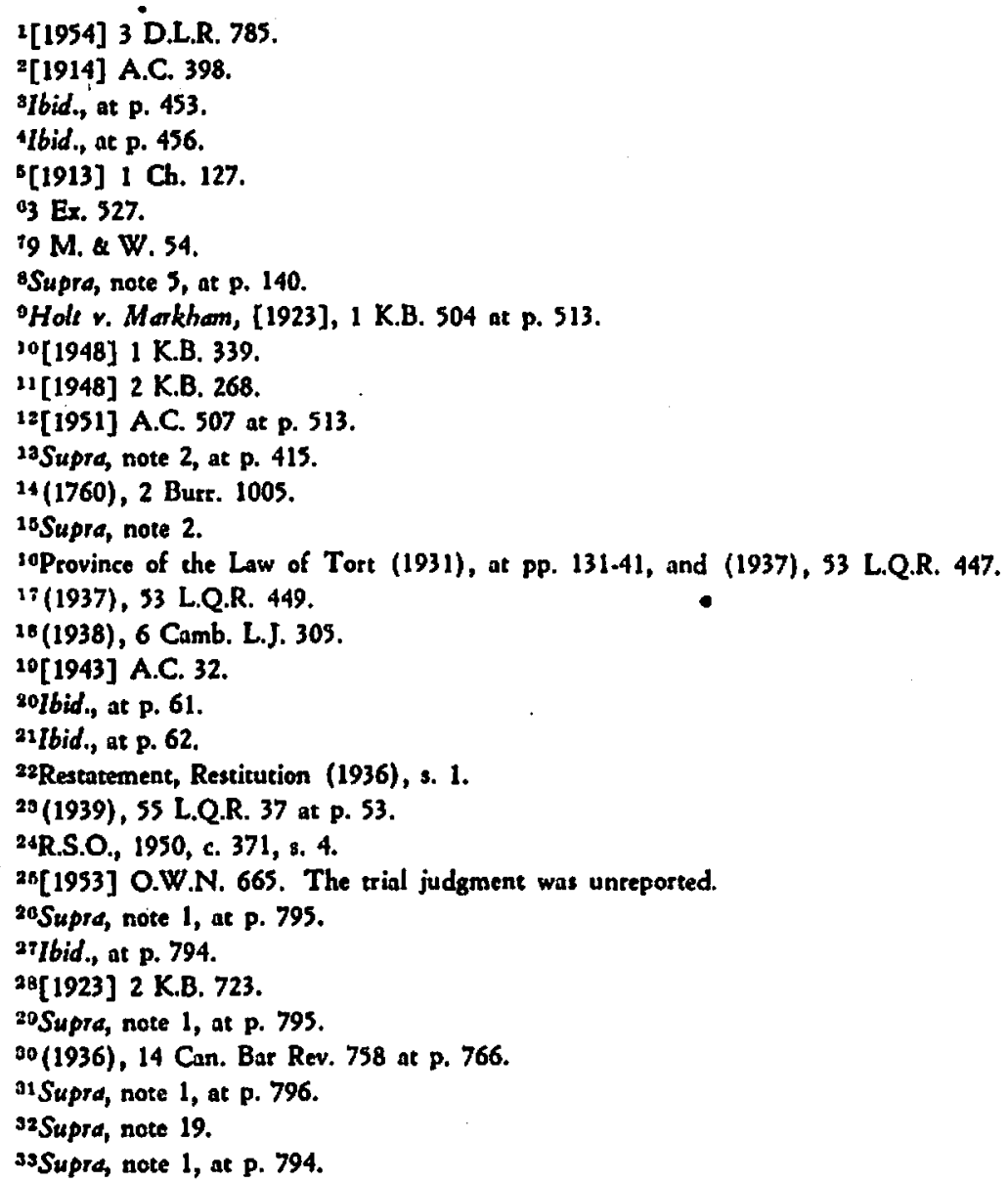

